University of Essex

SCHOOL OF ACCOUNTING, FINANCE AND MANAGEMENT

Public Sector Reforms, Privatisation and Regimes of Control in a Chinese Enterprise

Wen, $\mathrm{Xu}$

School of Accounting, Finance and Management

University of Essex

Shahzad Uddin

School of Accounting, Finance and Management

University of Essex

Working Paper No. WP 08/05

January, 2008 
Public Sector Reforms, Privatisation and Regimes of Control in a Chinese Enterprise

\author{
Wen, $\mathrm{Xu}$ \\ School of Accounting, Finance and Management \\ University of Essex \\ Colchester CO4 3SQ \\ and \\ Shahzad Uddin* \\ School of Accounting, Finance and Management \\ University of Essex \\ Colchester \\ CO4 3SQ \\ UK
}

*corresponding author 


\title{
Public Sector Reforms, Privatisation and Regimes of Control in a Chinese Enterprise
}

\begin{abstract}
The Chinese economic reform has recently become a major focus of attention around the world. The underlying rationale for the Chinese government's privatisation and public sector reforms is the view that reformed state enterprises and privately managed firms will demonstrate superior management control and better performance, and hence encourage economic growth and employment. There are very few intensive case studies published in English journals studying whether firms privatised in China have reversed previous losses and introduced better management controls, leading to increased investment, productivity, and overall organizational effectiveness and efficiency. The researchers do not seek to deny the control problems of Chinese SOEs, but question the consequences of the new controls installed during the post-privatisation period. The paper also reveals a declining tendency in employment; altered distributions of wealth - especially to the state - and labour, and a lack of improvements in the accountability of privatised companies. Overall, the paper argues, the aims of reform policies in China, including better control, increased profitability and an improved working life for Chinese people, have not materialized. The paper calls for more research on the above issues in the Chinese context.
\end{abstract}




\section{Introduction}

The Chinese economic reform has recently become a major focus of attention around the world, not only because of its unique combination of dynamic performance and unusual institutional arrangements but also because its gradualist strategy has produced real gross domestic product (GDP) growth of more than 9 percent per annum over the last 24 years (Wu, 1997). Currently, the Chinese economy is undergoing its third great institutional transformation of the reform period. As an important process in deregulating a centrally controlled economy, privatisation has been a significant component of the current economic reform and restructuring (Chen et al., 1992; McMillan \& Naughton, 1992). The underlying rationale for the Chinese government's privatisation and public sector reforms is the view that reformed state enterprises and privately managed firms will demonstrate superior management control and better performance, and hence encourage economic growth and employment. These issues have received enormous attention in Chinese civil society. There has been a debate among professionals and academics in China as to whether Chinese structural programmes, including public sector reforms and privatisation, promote growth or stimulate corruption, with insiders and government officials rigging sales for their own benefits (Green, 2003). Very few intensive case studies have been published in English journals on the contribution of these changing controls to performance changes and development goals in the context of public sector reforms and privatisation in China (Chen, 2005). This paper focuses on the above issues.

The "enterprise reform" stems predominantly from the advocacy of development economists that public sector reforms and privatisation can improve the governmental fiscal situation and the 
efficiency and performance of enterprises, and hence promote investment and economic growth in the long term (World bank, 1995). Whilst the policy makers are intoxicated by the "wonderful" prospects of China's reform, some studies have shown evidence of the other extremes ${ }^{1}$ (Liu, 2000; Jefferson, 1999; Nakagane, 2000). For example, Lang (2004) presented evidence to demonstrate that four private corporations "nibbled" public wealth in the process of privatising SOEs. Whilst previous studies in China have mainly focused on the financial performance of privatised companies, other issues relevant to broader reform programmes, such as the effects of ownership changes on management control, accountability and contribution to development goals, have remained under studied. This study, therefore, attempts to address this research gap in the Chinese context. This paper, drawing on Burawoy's factory regimes ${ }^{2}$ and political economy of development, seeks to understand the effects of public sector reforms and privatisation on control transformations, performance and accountability.

The paper is structured as follows: Section one presents the historical background of the Chinese economic reform and the current wave of privatisation. The theoretical background is discussed in section two, which also presents a literature review on privatisation and public sector reforms. A brief delineation of the research methods is presented next, followed by a section on empirical findings from a privatised bearing company. Finally, the paper concludes by returning to the original research questions.

\section{Chinese Economic Reforms and Privatisation}

China's economic reform dates back to 1978. Prior to the reform, the Chinese economy was a 
Soviet-type one ${ }^{3}$. China's economic reform process began with the Third Plenum of the $11^{\text {th }}$ Central Committee of the Communist Party of China (CPC) in December 1978. The Chinese authorities recognised the problems arising from the fact that administrative authority was unduly concentrated on the central government and enterprises lacked autonomy under the planned economy. As a result, the first reform experiment, covering just six large and medium-sized SOEs in one city, Sichuan Province, was undertaken in late 1978. The principal objective of the experiment was greater productive efficiency through expanding enterprise autonomy and creating incentives. Our case study also came under the same reform programme, as will be explained later. The reform program was expanded considerably in 1984 , with greater authority for SOEs to export and import, to create a mixed-ownership sector through horizontal integration between economic entities, such as state-collective joint ventures, and so on. Along with the 'dual-track' price system established in the same year, the scope of mandatory plan allocation was reduced (Wu, 1997, p.1239). This was extended to 58 cities by 1984 (Wu, 1997; Sun, 1994).

In 1987, the Chinese economic reforms took a new turn. First, policy makers set the principle of the 'state regulating the market and market conducting enterprises' instead of a highly centralised planning system (Wu, 1997). Second, in the same year, the Contract Responsibility System (CRS) was introduced into SOEs for the purpose of increasing productivity within the framework of continued state ownership by further separating the state's ownership of assets from the management of SOEs. This programme was also extended to our case study. It covered 90 per cent of SOEs, including 95 per cent of large and medium-sized industrial SOEs. Within SOEs, the CRS encouraged reorientation towards competitive and profit-seeking behaviour. However, many accountants and researchers agued that it had one fatal shortcoming, which was that managers could boost profits in 
the short term by decreasing depreciation allowances, postponing investment and neglecting asset maintenance. Although many reform programs had been implemented, the budget constraints in SOEs were still soft (Sun, 1994; Xu and Xiang, 1993). However, when over-heating of the economy appeared in China during the late 1980s, the government again emphasised planned control, and adopted a series of direct and administrative controls to curb the increasing inflation. In the early 1990s, particularly after China's senior leader Deng Xiaoping's 1992 "Journey to the South", the pace of China's transition accelerated. In 1992, the idea of 'corporatising SOEs' began formally, and a document on "Transforming the Management Mechanisms of State-owned Industrial Enterprises" was issued, which again emphasised the expansion of enterprise autonomy, economic liberalisation, and a further separation of government administration from enterprise management (McMillan and Naughton, 1992; Wu, 1997).

In 1997, Chinese economic reforms took another turn by introducing a shareholding system as the "mainstream reform program" for SOEs (Ma, 1998). The essence of the shareholding system reform was to convert SOEs into shareholding enterprises (SHEs). Shares were issued to the state, to enterprises and to individuals. Despite repeated denials by the government, the shareholding system reform is a form of privatisation, in the sense that it provides a channel through which state assets are transferred to private hands. Later in the same year, the premier Zhu Rongji declared a new strategy "seizing the big, letting the small go" - to reform large and small SOEs separately. It was proposed that property rights - at least of the strategically important sectors - must be kept firmly in the hands of the state, whereas small enterprises should be allowed to be privatised. This policy reflected the state's dilemma over the issue of privatisation. On one hand, privatisation was accepted by Chinese authorities and advocated for reducing the government's burdens and solving existing problems in 
SOEs. On the other hand, concern about losing ownership of state monopolistic industries and large well-performing SOEs prevented the government from initiating mass privatisation. From 1997 on, more than half of China's 159,000 SOEs have launched "enterprise reforms" - a euphemism for privatisation. In the clearest indication of which SOEs might be considered "big", the government formed the State-owned Assets Supervision and Administration Commission of the State Council (SASAC) in March 2003 to take over as custodian of 196 "centrally owned enterprises", which accounted for 64 percent of all SOEs' profits from various ministries. Since 2003, a fraction of these 196 state enterprises have been transformed into stock companies, part of whose stocks are on the markets, and encouraged to perform better. For the reform of small SOEs, as Li Rongrong, the director of SASAC, declared, " 85 percent of them have realized multi-level property rights through reforms until 2004." HS (anonymised here - the intensive case study) was also privatised during this period.

\section{PUBLIC SECTOR REFORMS, PRIVATISATION AND DEVELOPMENT}

Theoretically, public sector reforms and private ownership or management are often advocated on the basis of productive and allocative efficiency gains ${ }^{4}$. Production efficiency theorists argue, on the basis of neo-classical economic theories, that management controls and incentives induce low production costs, as they reinforce productivity targets. They further argue that productive efficiency is difficult in state-owned enterprises due to their political agenda and trade union involvement. Political interventions eventually lead to poorly motivated, badly paid and inadequately monitored managers (Hemming and Mansoor, 1988). Managerial efficiency is better related to the private sector, as its narrower objectives make it easier to devise efficiency-enhancing incentive contracts. This is 
underpinned theoretically by agency theory and property right theory (for details, see Uddin and Hopper, 1999). Proponents of these theories further advocate that privatisation of state-owned enterprises should be able to remove political interventions and will eventually bring a greater consumer focus, more cost control and a greater interest in making profit (Martin and Parker, 1997). However, a political economy of development emphasises that development aims should extend beyond financial profitability to issues such as poverty alleviation, narrowing income inequalities, and the quality of work experience. Rather than viewing firms as atomised economic actors, it views them as social institutions, inseparable from the society to which they belong (Thompson, 1982; Hodgson, 1988). A firm does not hold a simple and unambiguous goal but exists within conflicts of interest, constraints and obstacles (Thompson, 1982). Thus researchers should question the assumed relationship between ownership patterns and improved controls and seek explanations incorporating the complex factors that surround firms and society. Furthermore, neo-classical views pay little attention to inequities of power between labour and capital, or to the tendency of the state to act in the interests of dominant elites. For example, redundancies can create compliant internal and external labour markets (see Sobhan and Ahsan, 1984), which affect the feasibility of exerting coercive or consensual controls within enterprises. The rhetoric of productivity and profitability disguises the virtual elimination of collective bargaining and tight, harsh, arbitrary direct controls maintained by first line managers living in fear of dismissal (Uddin and Hopper, 2003). Similarly, Burawoy's (1985) prediction for privatisation is gloomy: it argues that coercive controls in a new despotic regime are likely to ensue in the absence of necessary protections for workers. Burawoy $(1979,1985)$ argues that the new despotic regimes of control in LDCs are based "not merely on the subjection of workers but on the mobility of capital. The need to maintain or attract capital instigates competition amongst enterprises, their labour forces, communities, and governments, resulting in policies that undermine 
protection and concession" from the previous regime - bureaucratic despotism (Uddin and Hopper, 2001, p. 652). Our paper investigates whether the same kind of phenomena exists in our case study.

Empirical research on the differences of management control between the public and the private or privatised sector is scarce and often inclusive ${ }^{5}$ (Boardman and Vining, 1988; Cragg and Dyck, 1999; Martin and Parker, 1997; Karatas, 1995; Jones, 1985; Tyrrall and Parker, 2001; Letza and Smallman, 2001). Very few studies have researched the changes in control, performance and accountability after privatisation in less developed and post-communist countries. Wickramasinghe (1996) found a number of changes of control in a privatised enterprise, including a reduction of bureaucracy, the unsuccessful introduction of private management control and failure to solve control problems, such as absenteeism, which existed during the public sector period. Uddin and Hopper $(2001,2003)$ argued that privatisation led to family-type control, with serious consequences for workers.

There is little empirical evidence regarding the effects of privatisation on management styles, especially in China. Nevertheless, previous studies have investigated the changes of accounting systems in the context of public sector reforms in the late 1980s and 1990s (Zhou, 1988; Bromwich and Wang, 1991; Scapens and Yan, 1993; Davidson et al., 1996). For example, Bromwich and Wang's (1991) study commented on the changing role of management control systems in SOEs in the context of public sector reforms. These studies did not examine the effects of privatisation on management controls. Recently, the work of Connor et al. (2004) has shed light on the adoption of "Western" management accounting and controls in SOEs in the midst of China's continued privatisation programme. To sum up, there is insufficient empirical evidence and great controversy surrounding the impacts of privatisation on management control and performance, indicating the 
need for more comprehensive and intensive studies. The authors' desire to address the research lacuna on the substance of these debates at an organisational level motivated the research reported here.

\section{Research Methods}

The study was restricted to one privatised enterprise because of access, finance and time constraints. The company is located in East Central China (where the researcher lived). After searching the SASAC database, 23 companies were found that had been privatised for at least one year. An introductory letter including the purposes and requirements of this research was posted to all 23 companies before implementing the research. Four SOEs responded, but only one of them agreed to be investigated. We adopted a triangulation approach to data collection, which included interviews, documentary evidence and observations. The theoretical insights adopted here also led us to adopt a qualitative methodology, giving the scope to iterate theoretical arguments with the empirics and generate future research ideas (Patton, 2002).

Owing to the complexity of the circumstances and the sensitivity of political factors in Chinese enterprises, the researcher (the first author) had to provide extra assurances of confidentiality to the interviewees, especially to the current managers. Full anonymity was provided to all interviewees. Semi-structured interviews were conducted in the enterprise to help the researcher gain useful insights from interviewees and guidelines to new areas that the interviewer was not aware of. Topics contained in face-to-face interviews with managers, accounting staff and employees included control strategies, organisational structures, incentive systems, production processes, marketing strategies, budgets, accounting systems and performance measures. In addition, interviews were also conducted 
with academics. Data was recorded by note-taking or by tape-recording the conversations. In total, 26 interviews were held, ranging from one to two hours in length. Interviewees consisted of two academics, eight former managers (who had worked in production and accounting departments respectively), twelve current managers (working in production, accounting and marketing departments) and four workers and lower level employees. The managers interviewed were from all levels. Both formers managers had worked during the pre-privatisation period (before and after 1978). Some of the current managers had worked in both periods, pre and post privatisation.

Documents, reports and manuals were collected from the SASAC research centre, libraries, newspapers and the enterprise itself. This information helped to validate the qualitative data from the interviews and provide important quantitative data. Documents and manuals served mainly as substitutes for records of activities that the researcher could not acquire through the interviews. Financial reports were obtained to measure performance changes. Documentary evidence and interviews corroborated and complemented the personal observations of the first author. We believe that a triangulation approach to data collection aids in the formation of a chain of evidence, which in turn provides explanations of events and issues (Miles and Huberman, 1994; Marshall and Rossman, 1999). We have thus made attempts to enhance internal and external validity by discussing contradictory evidence with our respondents and the academic community (Miles and Huberman, 1994).

\section{Empirical findings: The Case Study}

The case study was carried out in a large, recently privatised automobile bearing company in China, 
which was founded in 1968. The products of HS are mainly used for manufacturing automobile wheels. It was an important project for the government before the economic reform in China. HS underwent rapid expansion and became the biggest professional manufacturer of automobile bearings and one of the five biggest bearing export bases in China. Nevertheless, HS's ownership was restructured in 1978 and it was later sold to a private company in 2003. The following briefly discusses the changes of management styles at the different phases of ownership.

\section{Control under State ownership (Before and After 1978)}

This section presents the changes of controls in HS under state ownership (from 1968 to 2003). During this period, and especially after the company's ownership was restructured in 1978, HS was subjected to a number of reforms with regard to incentives and management controls. Nevertheless, the state's stake in HS remained unchanged until full privatisation in 2003. From its establishment, HS, as a part of China's central plan, was a unit under the jurisdiction of ZJ (anonymised), a state agency. In contrast to the notions of maximising profit and shareholders' wealth that characterise enterprises in market economies, the primary objectives of HS, as stated in official documents, were not only to make profit but also to satisfy social needs by fulfilling demand and providing employment (Jones and Sefiane, 1992). Thus, there were set controls to ensure that public funds were used legally and regulations governing prices, costs, revenue and capital cash inflows and outflows and employment in accordance with the central plan. This was an attempt to establish state capitalism (against feudalism) and secure surplus value to be distributed to the population via the state. State capitalism, as Burawoy has argued, eventually turned into a bureaucratic despotic regime at the organisational level, especially in communist countries (see endnote 2). Similar types of bureaucratic 
despotic regime appeared in Bangladeshi state-owned enterprises (Uddin and Hopper, 2001). Burawoy (1985) has also outlined the more interventionist role of the state during the bureaucratic regime in state-owned and non-state-owned enterprises in Zambia. This paper particularly seeks to understand how controls are exercised during the state's regime on the basis of formal accounting systems, bureaucratic rules and formal labour markets - features of bureaucratic despotism (Burawoy, 1985; Uddin and Hopper, 2001).

\section{Centralised and Bureaucratic Controls}

Like other state-owned enterprises, HS was controlled via various directives issued by the state's agency (ZJ). ZJ receive directions from the relevant ministries. As well as complex external control hierarchies, there was a long chain of control within HS. HS had eight functional departments, namely Administration, Accounts and Finance, Production, Quality Control, Engineering, Planning, Purchase and Marketing, and each of them had several managerial layers. The problem that existed in the organisational structure of HS was that the complexity of the vertical hierarchy led to communication difficulties between ZJ and HS. This problem was illustrated by a comment made by a former executive officer: Due to these layers, it was difficult for us to have realistic knowledge of the operation status of the junior units. The problems that basic units faced could not be communicated to the bureau immediately because of the complex layers of command. It is widely believed that overemphasis on applying detailed controls on the spending of state funds lead to complex bureaucratic chains of command. This is not unusual in SOEs, as previous studies have revealed (Wickramasinghe, 2005; Uddin and Tsamenyi, 2005). It is also part and parcel of bureaucratic despotism, as argued by Burawoy. 
The dominance of social welfare rather than economic objectives resulted in the government playing a leading role in setting prices for the enterprise's products during the central planning period (Jefferson and Rawski, 1994). Prices were determined on a cost-plus basis. However, unlike in market economies, "cost" was taken to be the average for the whole industry rather than that of the individual producer. A former manager remarked: Pricing was the responsibility of the government. We had no authority to set prices, so pricing was out of our consideration. As well as setting prices, the Planning Ministry also had overall jurisdiction concerning the planned levels of output of the enterprise. These levels were determined in the light of the national development policy and based on the previous year's output. Despite the emphasis on planning production, interviewees frequently commented that uncertainty about the availability of resources was so severe as to make planning complex and the synchronisation of operations very difficult. In particular, shortages of raw materials and spare parts and equipment failure resulted in wide deviation from production plans. This led to production plans being perceived as unattainable. The former head of a production department explained: Sometimes the suggested plans received from the bureau (ZJ) were unrealistic. There were many constraints that the bureau ignored. Production targets were often used as a political tool by the state's agency, as managers opined. ZJ officials often asked HS to meet output growth targets so that they could tout it as their policy achievement, even if HS could not sell all of its output at a profit. The major operational objective of HS was to fulfil production targets, and its marketing policy was in the hands of ZJ. HS had to sell its products through ZJ's depot or to the selected downstream enterprises directly. One former marketing manager confided: The enterprise was not market-oriented at that time because we could not sell our products through our marketing staff. We had no direct contact with our customers, so it was difficult for us to be responsive to their needs. 
Recruitment, promotion and all other major personnel matters were also controlled by ZJ. This bears similarities to other studies of management control in LDCs (Ouibrahim and Scapens, 1989; Wickramasinghe and Hopper, 2005; Uddin and Tsamenyi, 2005).

Accounting and Accountability to the State

Accounting and accountability was mainly designed to serve the workers' congress and state's agencies. The general manager was appointed by ZJ and was responsible through the elected worker congress, which was comprised of senior staff of the enterprise and workers' representatives. Managers' salaries were fixed and not linked to the enterprise's performance. One past manager said: Top management just followed ZJ's instructions and did not want to be over-involved with the enterprise because their wages were fixed no matter how much work they did. Managers and employees alike were not paid directly for their services at HS because anyone assigned to any work in the enterprise had to be treated in the same way. Instead, all the revenue earned by HS was handed on to ZJ to be lumped in with all other enterprises' incomes for distribution to the populace. Thus, conventional Western performance measures do not bear any semblance to the incentive systems established at HS.

Accounting in HS was under rigid, formal scrutiny at various government levels. The preparation, approval and dispatch of accounts to ZJ, the Industrial Ministry and the Planning and Finance Ministry followed strict rules and regulations. HS had to prepare budgets yearly and submit them to upper government agencies within the framework (based on national plans) set by ZJ. ZJ revised them based on the previous year's figures and the whole plan was set for all components. When 
budgets were approved, HS compared the variations between actual and target outcomes monthly in order to ensure stability of production, as the former chief accountant revealed. Interestingly, ZJ also set cost targets for HS along with the budgets. HS was required to submit reports on budgets and costs on a monthly basis. Cost figures from HS, along with other units within the same industry, played an important part in setting product prices. Thus, the role of the accounting department at HS was confined to providing supporting information to enable ZJ to calculate prices. This was illustrated by the comments of a former chief accountant: My contribution in such an operation was simply to provide the general manager with cost schedules and price documents on which he based his calculations. Once the necessary resources had been committed and prices established, they were communicated to the accounting department, which was only responsible for invoicing. HS, as a unit within ZJ, did not appear to have any independence to use any of the accounting calculations. The main objective of operating units such as HS seemed to be to produce and utilise machines and manpower in order to satisfy national output plans within the set cost target. As one former manager commented: the production plan was established by ZJ and it was compulsory for us to execute it. Accounting had less influence in the production process, except for translating the plans into figures. Furthermore, conventional planning and control tools were not very relevant to HS's day-to-day control, as one former manager opined. Managers in the accounting department were only interested in the flow of funds to pay bills, particularly salary and wage bills. This finding is strikingly similar to other studies on public sector firms in less developed countries (Wickramasinghe and Hopper, 2005; Alam, 1997; Ouibrahim and Scapens, 1989; Uddin and Tsamenyi, 2005). Uddin (1997) argued that the overwhelming political influence on enterprises rendered formal accounting irrelevant. The evidence from HS is supportive of Burawoy's suggestion that communist countries created bureaucratic despotisms in state enterprises. Through state ownership and legislation, the Chinese 
authority sought to regulate large enterprises and control workers by consent based on central state planning. These arrangements reflected their idealistic ideologies and their desire for rational development within a communist state that protected workers and farmers.

\section{Performance}

In contrast to the claims made by advocates of property rights, although managers' rewards were not directly related to economic performance, HS was still commercially successful. Managers had to control costs in order to meet the targets set by the government. Even though the researcher was unable to collect sufficient data on HS's production and capacity utilisation before 1978, it is undeniable that HS was the biggest manufacturer of automobile bearings and one of the five biggest bearing export bases at that time, as the fieldwork revealed. Its productivity was good compared to similar business enterprises in China. As remarked by a former production manager: We had considerable productivity and most of the time, capacity utilisation remained at approximately 80 percent. As the chief accountant recalled, HS never incurred a loss during this period, and its sales and profits increased every year: Basically, profits increased at an average of approximately 20 percent from 1975 to 1978 due to the enlargement of production. A former accountant commented: HS was considerably profitable, but all the profits were diverted to the government. Like other SOEs, HS was contributing to the generation of employment. HS, as a large SOE, employed 3970 people in 1968 and this number increased to 5892 by the end of 1978. Workers' rights were protected by trade unions and employee welfare was ensured following the government's rules and regulations. HS was required to provide not only medical care for current employees but also pensions for its retired workers. Under the central planned control system, all SOEs' profits were remitted to the government 
for fiscal reserve and distribution.

Changes of Control and Accounting after the Reforms in 1978

Bureaucratic despotism has withered in significance (though not in presence) as market rationality has been introduced to Chinese SOEs by communist party leaders over the last three decades. HS also became a part of the programme as various reforms in ownerships started to come to the fore. The government's attempt to separate the state's ownership from its regulatory functions accelerated the construction of a shareholding system and the creation of a multi-tiered network of state asset management system at national, provincial and municipal government levels. Based on this background, HS was placed on the list for stock system reconstruction and all the government's shares were transferred from old line bureaux to a municipal state asset management company (SC), which was monitored by the State Asset Management Committee (SAMC) at the provincial level and finally by SASAC. However, the separation of ownership and control did not result in a reduction of governmental interference in HS as expected. One manager remarked: In fact, government control became tighter than before. In contrast to what the government stated, SC continued to be more bureaucratically rather than commercially oriented. The predominant method of creating holding structures along industry lines tended to mix the regulatory and commercial objectives of SC, because it was still heavily influenced by the state's agency, SAMC, which continued to function like a government administrative department. At the same time, despite the reform objective of separating the government from enterprise management, the political/bureaucratic intervention in the managerial selection process still existed, as reported by managers in HS. 
Along with the economic transition, the Finance Ministry set out to transform the bureaucratic accounting system to allow the economic system to work (Davidson et al., 1996). Rather than passively carrying out the instructions of central planners, SOEs were officially made responsible for their own profits and losses. The basic function of accounting information, therefore, shifted from implementing macroeconomic planning and safeguarding national assets to decision-making by enterprise management and external markets. Similar findings were also reported in Bromwich and Wang's (1991) study on Chinese SOEs. One former manager added: As a result of separating ownership and management, we were granted autonomy for inventory purchasing, productive mix, pricing and retained earnings distribution. Management accounting, therefore, became a useful and indispensable instrument for our business decision-making. Soon after the reforms in 1978, a new office under the executive manager - the 'management office' - was established in HS so that accounting managers could play a role in assisting top management. The operational budgeting process became more independent and flexible, according to one former manager. Market information received more attention in the preparation of production budgets. Computerised systems for recording information speeded up the supply of internal information for decision-making, as the chief accountant confirmed. Along with the internal reporting, the external reporting system of all Chinese enterprises also saw gradual change changed. The issuing of the "Accounting Standards for Business Enterprises" (ASBE) in November 1992 changed the accounting format for SOEs. Under the ASBE, all SOEs, including HS, were required to adopt the standards and follow the reporting format. Accounting reports had to be submitted to the local Administration Bureau of Industry and Commerce for inspection at the end of each year. However, these standards did not lead to major changes in internal accounting practices; rather, they merely increased the accounting department's workload, as one accountant claimed. 
Changes also extended to managerial incentives and other governance measures. These were centred mainly on expanding managerial autonomy and incentives through contracts between managers and the government supervisory agency. In particular, the establishment of $\mathrm{CRS}^{6}$ (the contract responsibility system) intended to provide greater material incentives for managers and workers by way of management autonomy, pay and retained profits to the performance of SOE. Nevertheless, this was not really reflected in the performance figures, as will be shown later. Some managers, however, opined that changes in the profit allocation system stimulated the managers' enthusiasm. In addition, in 1986 the Bankruptcy Law was promulgated to provide superficial risks to SOE managers. According to documents, if a SOE failed to generate sufficient profits, it could, in principle, become bankrupt. However, with government protection, bankruptcy was not a real threat for most SOEs in China. One senior manager mentioned: Bankruptcy was not a threat for us, since we knew the government would not let us face it. Even though the performance of HS worsened year by year, it was also easy for us to obtain loans because of the government's intervention. In the subsequent SOE reform program, a major focus was given to the separation of government ownership and regulatory functions by establishing the state as a shareholder with functions similar to those performed by private shareholders. Corporate governance mechanisms, which materialised as a two-tier board structure, were introduced to HS. The intention was to ensure effective corporate governance through the accountability of management to the board and shareholders; supervision and oversight of the board of directors and senior management by the supervisory board; and the accountability of the directors to the shareholders. However, these mechanisms did not seem to have any serious impact on accountability, as many interviewees opined. Some pointed out fatal flaws in the board structure: the roles of chairman of the board and general manager were combined and the board was dominated by 
the executive director, who had managerial responsibility ${ }^{7}$.

\section{[Insert Figures 1, 2, 3 near here]}

\section{Changes to performance and preparations for full privatisation}

Although some managers of HS stated that their incentives had been stimulated and reoriented to engage in profit-driven and value-augmenting activities, the data abstracted from HS's previous reports show a decline in production and capability utilisation. For example, HS's productivity dropped by 46.23 percent from 1978 to 1990 . Although productivity rose from 1991, it could not reach the levels attained in 1978. Overall capacity utilisation decreased from 87 percent in 1978-79 to 31 percent in 2001-02. Detailed examination of annual reports from 1978 to 2002 clearly reveals the deterioration in HS's performance. Its Return of Assets rate (ROA) was 22 percent in 1978 but had fallen to below 5 percent by 1990 (Figure 1). The executive manager attributed this decline in profit to the increasing competition engendered by the entry of non-state firms. He added: Social burdens such as surplus labour, high tax rates and expenses for medical care, pensions, housing and education were quite substantial (compared to the non-state firms). HS's performance did gradually recover after a proportion of its employees were retired in 1991. Sales escalated progressively from 134.24 million RMB in 1991 to 194.55 million RMB in 1998. Profits fluctuated slightly during this period, reaching a peak at 23.98 million RMB in 1998 and bottoming out at 14.33 million RMB in 1992 (Figure 2). In May 1995, HS experienced stock system reconstruction. Its Return on Equity (ROE) diminished gradually, from 15.03 percent in 1995 to 10.02 percent in 1998 (Figure 3). However, HS's economic and financial performance deteriorated noticeably from 1998. The RMB 
194.55 million sales in 1998 dropped to RMB 120.57 million in 2002. Meanwhile, profits fell from 23.98 million RMB in 1998 to -41.57 million in 2002. Since 2002, the worsening financial performance has disconcerted the management of HS and SC. Claims that poor SOE performance is attributable to "unclear property rights" led the government to present privatisation as a solution for HS's performance failure.

\section{New control regime under private ownership (Since 2003)}

In 1997, the Third Plenary Session of the $15^{\text {th }}$ Party Congress first officially endorsed the exit ("divestiture") of small and medium SOEs from state control and responsibility. Following the official decision, local governments quickly embarked on programs to restructure and divest their SOEs. Their objectives were explicit: to reduce government burdens and responsibilities for public enterprises, while improving their capabilities to successfully compete in a market environment (OECD, 2000). The context is very similar to other less developed and East European countries. Burawoy (1985) argues that fiscal crises and pressures from agents of international capital for market reforms cause bureaucratic regimes (state capitalism) to decline in less developed countries. This pattern of events has been discernable in China. Burawoy (1985) argues that states often turn to programmes of economic liberalisation based on export processing zones, privatisation, and touting the attractions of cheap, economically weak, unprotected labour to local and foreign capital. Consequently, this leads to new despotic regimes of control in LDCs where workers must accede to coercive and unilateral management control under the threat of the relocation of capital. This is especially acute in LDCs, given the poverty of their states and populace (Uddin and Hopper, 2001, p.

652). This paper seeks to investigate whether the above predictions ring true in the Chinese context, 
especially at HS. HS was fully privatised in May 2003. The government sold 73.58 percent of their shares to a private company, and transferred the remaining 26.42 percent to the management of HS. Changes to controls and accounting are discussed below.

\section{De-Layered Controls}

After privatisation, HS became decentralised and de-layered. The management quickly reduced the vertical chain of command and promoted horizontal development. The eight former departments were restructured and the layers between upper departments and basic operation units were reduced. Although the private company remains the dominant shareholder of HS, top managers have also become shareholders in the company. Consequently, top managers now have more power to exercise control over workers and lower level employees than ever before. One top manager remarked: We have more autonomy to make decisions on the enterprise's operation than before. From my point of view, the removal of government intervention is only one reason for our increasing authority. More importantly, we are now not only employees, but also shareholders of $H S$.

A number of changes have occurred in the operations of functional departments. For example, the new owners introduced a management control instrument - Comprehensive Enterprise Management Software - to HS, which combined and processed information from all departments together. This helped top managers, especially the dominant shareholder, to master changes of operation status in good time. The marketing department was restructured. A new sale force was enrolled and a large investment was granted to the marketing department for their restructuring and training. One marketing manager commented: Customers' requirements force our production department to 
produce high quality bearings and urge our technology department to design customised products. Compared to pre-privatisation, their requirements are now gathered at every opportunity and quickly incorporated into our production plan. For the international market, a professional marketing group, consisting of experienced marketing staff and graduated marketing students, was contracted especially to enter into the international bearing market.

Accounting and Accountability to Shareholders

The New Regime did not require significant changes to accounting reporting. HS still maintains the management accounting and external reporting systems that it used previously and submits financial reports to the inspecting institution as usual. The director appointed by the dominant shareholding company goes through the financial reports monthly in order to ensure that the operation is under control. No extra reports need to be presented to the other shareholders, as the chief accountant confirmed. HS apparently compiles its annual reports in adherence to regulatory requirements and submits them periodically for inspection purposes. However, the budget preparation and performance measurement processes have changed since privatisation. As mentioned earlier, budgets are now more market-oriented, but are centralised. A budget, prepared and seen by the departments of Accounting, Production, Marketing, Purchasing and Administration, is submitted to shareholders' meetings twice a year. Top managers and the dominant shareholder (one private company) now have more control over budgets and performance. Changes to top management's incentives since privatisation now favour owner-managers. The private owner has introduced a new compensation system, which aligns managers' incentives with its financial interest. One manager specifically highlighted the link between the firm's performance and his job prospects: The primary reason why 
we focus on the market is that we possess shares. The better HS is, the brighter our own future will be. In addition, our personal reputation is also a consideration. The minute we lose shareholder support, the survival of the firm and ourselves is on the line. Another manager added: Under public ownership, managers did not take the long-term development of HS into account due to their durations of duties. After privatisation, we must pay more attention to development strategies for HS, because our personal benefits are hooked up with the performance of the enterprise. This system was especially designed to allow the top management (who also own shares) to reap the benefits of the company's growth as much as possible.

Changes are also extended to performance measurement for employees. Incentives and wages have actually got worse for workers in some ways, as the fieldwork has revealed. For example, a whole new reward-penalty system was initiated to control employees' performance. Their wage criteria were subdivided into 12 grades, and extraordinary awards were set up for encouragement purposes. As one manager said, it introduced competitiveness among workers and employees. At the same time, the system put enormous pressure on workers to perform. According to Burawoy (1979), these arrangements on the shop floor often give rise to gaming behaviour. In addition, the reorganisation of internal labour markets helped the management to introduce lateral conflict in place of hierarchical conflict, which ultimately helped to increase the surplus labour for shareholders and owner-managers. Further, the authors argue that the state's privatisation process facilitated the introduction of new labour markets and increased individualism within the organisation. For example, just before the sale of the state's shares, HS laid off 3046 employees. Soon after privatisation, 1109 of these employees were re-employed under new contracts. Interestingly, these were temporary contracts, which denied the workers fringe benefits. This form of casualisation is also seen elsewhere in privatised companies 
around the world (Uddin and Hopper, 2001). We would argue that such redundancy and reappointment not only helped the company to set new game rules for employees, but also introduced the fear of being laid off, which ultimately put a serious dent in the strength of the internal state, i.e. trade unions (see Burawoy, 1979, 1985; Uddin and Hopper, 2001). Consequently, this helps the new regime to continue to set or change workers' job descriptions as they see fit. Interviews with workers revealed that control at HS became harsh and intensive after privatisation at HS. One manager commented: workers are given further responsibilities to comply with the new tasks imposed on them. For example, no new workers have been appointed since privatisation, despite the introduction of a number of new product lines.

\section{[Insert Table One here]}

Changes to performance and distributional issues

The above changes were expected to produce good results for capital. Nevertheless, the annual reports show interesting but inconclusive results. Sales declined from 120.57 million RMB in 2002 to 107.38 million in 2003 , but interestingly net profit climbed from -41.57 million RMB to 3.92 million RMB. The most recent annual report reveals that HS's profits accrued moderately, from 3.92 million RMB in 2003 to 6.33 million RMB in 2004 (Figure 2). In the meantime, ROE soared from -23.30 percent in 2003 to 3.58 percent in 2004 . These anomalies can be explained by the fact that the prime (gross) operating profit of HS remained low, at -25.89 million RMB; however, its income from investment, non-operating earnings and subsidy revenues increased tremendously, from -0.79 million RMB in 2002 to 38.79 million RMB in 2003. These figures indicate that privatisation did not 
improve the performance of HS's main businesses dramatically. However, HS's productivity shows an increase of 21.3 percent from 2003 to 2004 . This clearly reflects a declining number of workers at HS after full privatisation. This trend is also reflected in other SOEs and privatised enterprises (see Table One). As mentioned earlier, HS laid off 3046 employees just before privatisation. We would argue that laying off employees before privatisation was not only to reduce labour costs, but was also a strategy for obtaining shares cheaply. According to the rules set by the municipal government, each displaced employee could obtain at most 31,800 RMB as compensation for terminating their lifetime employment contracts. After paying a total of 96 million RMB, HS's net asset value plummeted. This helped the management and the outside shareholder to purchase the government's shares at a low cost. HS also charged future compensation for the existing 722 employees to the 'liabilities account' in order to reduce payments. The chief accountant explained: The way we dealt with these transactions was in accordance with the government's rules. In 2000, the municipal government enacted a policy and allowed SOEs to charge expenses for displacement of employees in advance. We argue that the whole process of privatisation ${ }^{8}$ leads to the transferral of massive public wealth into private hands. This is not uncommon, having been reported in many countries (Uddin and Hopper, 2003). The authors also note that HS's contribution to GDP remained at nil after privatisation, because HS's profits were used to offset previous losses in accordance with the Taxation Law.

\section{Concluding Remarks}

This paper set out to understand the changes of controls, performance and accountability in a privatised company in China. Our findings suggest that the transformation of ownership is not a 
sufficient or essential condition for superior management controls, better performance or broader development goals. During the period of state ownership, HS was operating under the state's plans and control. Control was primarily secured by bureaucratic commands, often for political gains rather than commercial ends. Detailed systems of control and accountability were maintained but became ritualistic and de-coupled from operations. Burawoy's depiction of bureaucratic despotism seems to be a useful analytical tool to articulate the control regime during the state ownership of HS. This is consistent with other studies in LDCs (Ouibrahim and Scapens, 1989; Uddin, 1987; Jones and Sefiane, 1992; Wickramasinghe, 1996). Nevertheless, HS was a profitable concern during the state's ownership, with many of the benefits flowing to the government. HS generated employment and made significant contributions to the state's coffers significantly. However, in a bid to match the central reform plans, HS's ownership was changed in 1978. This was an attempt to separate the enterprise from the central Chinese Authority without selling shares to the public. As we argued earlier, bureaucratic despotism declined in significance but still maintained its presence during this period in HS. Financial accounting and budget systems changed following reforms. HS had to comply with the accounting standards. Reforms also led to control changes, including the introduction of a contract responsibility system, budgeting and new governance mechanisms, manifested as a two-tier board structure. Nevertheless, state bureaucrats and political cadres retained their hold over major decisions: problems associated with bureaucracy and politicisation persisted. HS's performance did not improve much following the reforms in 1978. By 1991, HS had seen some improvements, such as the escalation of sales and fluctuating profits. This continued until $2002-\mathrm{a}$ year before full privatisation.

HS was fully privatised in 2003 in order to improve control and performance. Our evidence indicates 
that HS maintained the external reporting system used previously. Controls were changed, with severe consequences, particularly for workers and lower level employees. Budgets are now more market-oriented but centralized. Lower level managers exert little influence on controls but execute managerial command, directly influenced by the dominant shareholder. Controls over employees have become coercive. Increased control over workers was established by the increased use of low paid, temporary labourers, and by widespread redundancies. These actions were justified by a rhetoric of market economy and accounting priorities such as cost savings, productivity and profitability. Employee resistance was minimal. Neo-classical assumptions that private ownership would make controls more commercial were, to a degree, correct. Budgetary controls have become more flexible, being focused on market information rather than production, as was previously the case. Nevertheless, private ownership has brought managerial technologies, including the introduction of new internal labour markets, and following widespread redundancies, most workers are now hired on a temporary basis with little state protection, with severe consequences for workers, society and the country in general. The changes have increased worker conflict and rendered workers powerless. These changes of controls are consistent with Burawoy's prediction of coercive control within a new despotic regime.

Furthermore, there is no evidence of any benefits of privatisation trickling down to labour: wages have declined and there is an ill-paid group of casual workers. The evidence also suggests that changes in management control and incentives have not reinforced productivity targets. HS's productivity and capability utilisation have declined considerably since the beginning of the economic reform. Although these indices surged slightly following privatisation, they still remained lower than they had been prior to reform. It may be too early to judge the effects of privatisation upon HS's 
commercial performance at this point, as a simple comparison of financial results in different periods without considering the influences of inflation and government protection may be misleading. However, it is undeniable that HS's performance has deteriorated since the adoption of superior management control. Despite the sudden escalation of HS's profits following privatisation, there was no marked improvement in the performance of its main business, which continued to make losses. . Contributions to state coffers also diminished. Accounting reporting and accountability remained unchanged. The transparency of the privatisation process has been a focus of debate in Chinese civil society. The trend found in the case study - sudden increases in HS's losses and profits around the privatisation event - is not a unique event, as other studies have indicated similar patterns (Wu, 1997; Uddin and Hopper, 2003). These findings support the suspicion that privatisation may redistribute public wealth to private hands.

Overall, this paper does not wish to deny that there are control problems in state-owned enterprises in China. Nevertheless, contextual problems in China, such as huge income gaps, poverty and other structural conditions, render neo-classical solutions ineffective. Recently, the IMF and other monetary agencies called for state intervention in China, as the economy was overheating. Thus, in keeping with other recent studies elsewhere, this paper questions the effectiveness of the privatisation and structural adjustment programmes in China (Uddin and Hopper, 2001, 2003; Wickramasinghe, 1996; Wickramasinghe and Hopper, 2005, 2006). Our case study evidence is more in line with a political economy perspective, which is sceptical about whether promoting private property rights will necessarily improve enterprise controls and profitability, or whether such accomplishments will necessarily lead to the attainment of development goals. The observations in HS and previous studies extend these arguments further, suggesting that even where owners have direct access to controls, 
property right predictions may not materialise. As Wortzel and Wortzel (1989) comment: "Private sector ownership is no guarantee of good performance. Private sector firms in every corner of the world go bankrupt every day. The determinants of the firm's success or failure are not who owns it" (p.639). In China, control problems in state-owned enterprises are associated with political interventions and wider socio-economic institutional arrangements. We argue that these political linkages will not go away simply as a result of a change in ownership or of implementing reforms, as observed earlier in HS. Relationships and motivation are more complicated than agency theory predicts, and it may be beyond its scope to model them (Armstrong, 1991). Previous accounting research has highlighted that the relationship between a manager's efforts and a firm's outputs in terms of profitability can be more difficult to identify and measure than is alluded to (Hopper et al., 1986). Similarly, accounting controls, central to privatisation policies, are socially and politically constructed, be they in the private or the public sector, as argued in a number of seminal accounting research papers (Burchell et al., 1980; Tinker, 1980; Neimark and Tinker, 1986; Hopper et al., 1987). Thus, we argue, it is unwise to assume that the efficient forms of accounting controls expected by productive efficiency theories will automatically flow from policies advocating privatisation.

Drawing on the political economy of development and Burawoy's factory regimes, we would like to argue that structural adjustment policies such as privatisation serve the few, instead of many billions. Our intensive case study evidence and previous studies in LDCs and developed countries strongly support the above concerns. The case study shows how a handful of managers and political cadres are able to capture state-owned enterprises. Uddin and Tsamenyi (2005) raised similar concerns in Ghana. Uddin and Hopper's (2003) research found that privatised companies had not only failed to contribute to the state coffers but had also increased social costs via redundancies and casualisation. 
Haselipa et al. (2005), in Argentina, found that public sector reforms and privatisation eventually increased income inequality and unemployment, and led to a weakening of social security. Studies in developed countries reveal the same story (Crompton and Jupe, 2003; Arnold and Cooper, 1999; Shaoul, 1997). These studies argue that a similar redistribution of wealth has been evident in the aftermath of privatisation in various sectors. Finally, the paper calls for more research on privatisation in China, especially focusing on the consequences of privatisation on the distribution of wealth and power, the despotic control of workers and the emergence of crony capitalism in China and elsewhere (Burawoy, 1985, 1979; Uddin and Hopper, 2001).

\section{References}

Adam, C., Cavendish, W. and Mistry, P.S. (1992). Adjusting Privatisation-Case studies from Developing Countries. London: Currey.

Alam, M. (1997). Budgetary process in uncertain contexts: a study of state-owned enterprises in Bangladesh. Management Accounting Research, 8, pp.147-168.

Andrews, W.A. and Dowling, M.J. (1998). Explaining Performance Changes in Newly Privatised Firms. Journal of Management Studies. 35 (5). pp 601-617.

Armstrong, P. (1991). Contradiction and social dynamics in the capitalist agency relationships. Accounting, Organizations and Society. 16, pp.1-25.

Arnold, P. and Cooper C. (1999). A Tale of Two Classes: The Privatization of Medway Ports. Critical Perspectives on Accounting. pp.127-152.

Balassa, B. (1982). Disequilibrium Analysis in Developing Countries: An Overview. World Development, 10(12).pp.1027-1038.

Barnett, S. (2000). Evidence on the Fiscal and Macroeconomic Impact of Privatisation. IMF Working Paper WP/00/130. Washington, DC: IMF.

Broadman, H. (2001). The Business(es) of the Chinese State. World Economy. 24(7). pp.849-875.

Bromwich, M. and Wang, G.Q. (1991). Management Accounting in China: A Current Evaluation. The International Journal of Accounting. 26. pp.51-66. 
Boardman, A.E. and Vining, A.R. (1988). The Advantages and Disadvantages of Mixed Enterprises. Research in International Business and International Relations. 1. pp.221-244.

Bonoma, T. (1985). Case Research in Marketing: Opportunities, Problems and Process. Journal of Marketing Research. 2 (2). pp.199-208.

Bös, D. (1991). Privatisation: A Theoretical Treatment. Oxford: Oxford University.

Catchpowle, L. and Cooper, C. (1999). No Escaping the Financial: The Economic Referent in South Africa. Critical Perspectives on Accounting. 10 (6). pp.711-746.

Burchell, S. C., Clubb, C., Hopwood, A., Hughes, J. and Nahapiet, J. (1980). The role of accounting in organizations and society. Accounting, Organizations and Society, 5, 5-28.

Burawoy, M. (1979). Manufacturing consent. University of Chicago Press.

Burawoy, M. (1985). The politics of production. London: Verso.

Chen, K, Jefferson, G, and Singh, I. (1992). Lessons from China's Economic Reform. Journal of Comparative Economics, 16 (2). pp. 201-225.

Chen, J-J.J. (2004). Transformation of Rural China: How Local Institutions shape Property Rights in China. London: Routledge.

Chen, J-J.J. (2005). The Path of Chinese Privatisation: A Case Study of Village Enterprises in Southern Jiagnsu. Corporate Governance. 13(1). pp. 72-80.

Connor, N.G., Chow, C.W. and Wu, A. (2004). The Adoption of "Western" Management Accounting/Controls in China's State-owned Enterprises during Economic Transition. Accounting, Organisations and Society. 29. pp.349-375.

Cook, P. and Kirkpatrick, C. (1988). Privatisation in Less Developed Countries: An Overview. Chapter 1, pp.3-44, in P Cook and C Kirkpatrick (eds). Privatisation in Less Developed Countries, New York: Harvester Wheatsheaf.

Cook, P. and Kirkpatrick, C. (1995). Privatisation Policy and Performance. Chapter 1, pp.3-27, in P Cook and C Kirkpatrick (eds). Privatisation Policy and Performance: International Perspectives. New York: Harvester Wheatsheaf.

Cragg, M.I. and Dyck, I.J. (1999). Management Control and Privatisation in the United Kingdom. The RAND Journal of Economics.30(3). pp.475-497.

Crompton, G and Jupe, R. (2003). Such a Silly Scheme: The Privatisation of Britain's Railways 1992-2002. Critical Perspectives on Accounting. 14(6). pp.617-645. 
Davidson, R.A., Gelaridi, A.M.G. and Li, F.Y. (1996). Analysis of the Conceptual Framework of China's New Accounting System. Accounting Horizons. 10 (1). pp.58-74.

Duch, R.M. (1991). Privatising the Economy: Telecommunications Policy in Comparative Perspective.Ann Arbor: University of Michigan Press.

Dyer, W.G. and Wilkins, A.L. (1991). Better Stories, Not Better Constructs, to Generate Better Theory. Academy of Management Review. 16 (3). pp.613-619.

Enderwick, P. (1994). Multinational Enterprises and Partial Privatisation of State-Owned Enterprises. International Business Review. 3 (2). pp.135-147.

Espeland, W.N. and Hirsch, P.M. (1990). Ownership Changes, Accounting Practices, the Redefinition of the Corporation. Accounting, Organisation and Society. 5 (1/2). pp.77-96.

Green, S. (2003). Will privatisation in China work? paper presented to the Royal Institute of International Affairs, November.

Grosfeld, I. and Nivet, J.F. (1999). Insider Power and Wage Setting in Transition: New Evidence from a Panel of Large Polish Firms. European Economic Review. 43.pp.1137-1147.

Groves, T. and Hong, Y.M. and McMillian, J. and Naughton, B. (1994). Autonomy in Incentives in Chinese State Enterprises. Quarterly Journal of Economics. 109. pp.183-209.

Hemming, R. and Mansoor, A.M. (1988). Privatisation and SOEs. Washington DC: IMF Occasional Paper, No.56.

Haselipa, J., Dynerb, I and Cherni, J. (2005). Electricity market reform in Argentina: assessing the impact for the poor in Buenos Aires. Utilities Policy, 13(1). pp. 1-14.

Hopper, T., Cooper, D., Lowe, T., Capps, T. and Mouritsen, J. (1986). Management control and worker resistance in the NCB: financial control in the labour process. In Knights, D. \& Willmott, H., Managing the Labour Process. Aldershot: Gower.

Hopper, T., Storey, J. and Willmot, H. (1987). Accounting for accounting: towards the development of a dialectical view. Accounting, Organizations and Society, 12, 437-456.

Hjalmarsson, L. and Veiderpass, A. (1992). Productivity in Swedish Electricity Retail Distribution. Scandinavian Journal of Economics. October. pp.193-206.

Hodgson, G., Economic and Institutions: A Manifesto for a Modern Institutional Economics, (Polity Press, 1988).

Jefferson, G.H. (1999). Are China's Rural Enterprises Outperforming State Enterprises? Estimating 
the Pure Ownership Effect', pp.279-287, in Jefferson, G..H. and Inderjit, S. (eds) Enterprise Reform in China. Ownership, Transition, and Performance, Oxford: Oxford University Press.

Jensen, M.C. and Meckling, W.H. (1976). Theory of the Firm: Managerial Behaviour, Agency Cost and Ownership Structure. Journal of Financial Economics 3. pp.305-360.

Jefferson G.H. and Rawski, T.G. (1994). Enterprise Reform in Chinese Industry. The Journal of Economic Perspectives. 8 (2). pp.47-70.

Jia, J. Sun, Q. and Tong, Wilson H.S. (2002). Privatisation in Transition Countries: A Sampling of the Literature. IMF Working paper 99/6. Washington, DC: IMF.

Jones, C.S. and Sefiane, C.S. (1992). The Use of Accounting Data in Operation Decision Making in Algeria. Accounting, Auditing and Accountability Journal .5(4). pp.71-83.

Jones, C.S. (1992), 'The attitudes of owner-managers towards accounting control systems following management buy-outs', Accounting, Organizations and Society, Vol. 17, No. 2, pp.151-168.

Jones, C.S. (1985). An empirical study of the role of the management accounting systems following the take-over or merger. Accounting, Organizations and Society. 10(2). pp.177-200.

Karatas, C. (1995). Has privatisation improved profitability and performance of the public enterprises in Turkey?', Chapter 14, pp.244-262, in P Cook and C Kirkpatrick (eds). Privatisation Policy and Performance: International Perspectives. New York: Harvester Wheatsheaf.

Kay, J.A. and Thompson, D.J. (1986). Privatisation: a Policy in Search of a Rationale. Economic Journal. 96. pp.199-207.

Lang, X. (2004). property right reform of SOEs (n.d.), viewed 27 August, 2004. .http://www.phoenixtv.com/home/zhuanti/xwshj/langxianping01/index1773.html..

Letza, S. and Smallman, C. (2001). In pure water There is a Pleasure Begrudged by None: On Ownership Accountability and Control in a Privatised Utility. Critical Perspectives on Accounting. 12. pp.65-85.

Liu, D.Q. (2000). Does Property Right reform Improve the Productivity of State-Owned Enterprises? The Economic Review. 51 (1). pp.92-96.

Ma, S.Y. (1998). The Chinese Route to Privatisation: The Evolution of the Shareholding System Option. Asian Survey. 38 (4). pp.379-397.

Marshall, C. and Rossman, G. B. (1999). Designing Qualitative Research, 3rd edition (Thousands Oaks, CA: Sage Publications).

Martin, S. and Parker, D. (1997). The Impact of Privatisation: Ownership and Corporate 
Performance in the UK, London and New York: Routledge.

McMillan, J. and Naughton, B. (1992). How to Reform a Planned Economy: Lessons from China? Oxford Review of Economic Policy. 8 (1). pp.130-143.

Megginson, W.L., Nash, R.C. and Randenborgh, M. Van. (1994). The Financial and Operating Performance of Newly Privatised Firms: an International Empirical Analysis. Journal of Finance. 49 (2). pp. 403-452.

Megginson, W.L. (2005). The Financial Economics of Privatisation. Oxford: Oxford University Press.

Miles, M. B. and Huberman, A. M. (1994). Qualitative data analysis, (2nd ed.). Thousand Oaks, CA: SAGE

Millward, R. (1988). Measuring Sources of Inefficiency in the Performance of Private and Public Enterprises in LDCs. Chapter 6, pp.143-161, in P Cook and C Kirkpatrick (eds). Privatisation in Less Developed Countries. New York: Harvester Wheatsheaf.

Nakagane, K. (2000). SOE Reform and Privatisation in China: A Note on Several Theoretical and Empirical Issues. Working Paper CIRJE-F-95. University of Tokyo.

Neimark, M. and Tinker, T. (1986). The social construction of management control systems. Accounting, Organizations and Society, 12, 369-395.

Neu, D., (1991). Trust, Contracting and the Prospectus Process. Accounting, Organizations and Society. 16(2). pp.243-256.

OECD. (2000). Reforming China's Enterprises. Paris: OECD Publications.

Ouibrahim, N. and Scapen, R. (1989). Accounting and Financial Control in a Socialist Enterprise: A Case Study from Algeria. Accounting, Auditing and Accountability Journal. 2(2). pp.7-28.

Patton, M. Q. (2002). How to Use Qualitative Methods in Evaluation, 2nd edition (Newbury Park, CA: Sage Publications).

Peacock, A. (1984). Privatisation in Perspective. The Three Banks Review, No.144, December.

Picot, A. and Kaulaman, T. (1989). Comparative Performance of Government-owned and Privately-owned Industrial Corporations - Empirical Results from Six Countries. Journal of Industrial and Theoretical Economics. 145. pp.298-316.

Sampon, C.I. (1995). Privatising Banking Services in Jamaica in J. Prokopenko (ed). Management for Privatisation: Lessons from Industry and Public Service, Geneva: International Labour Office. 
Sauders, M.L. and Thornhill, A. (2003). Research Methods for Business Students, NJ: Prentice Hall.

Schwartz, G. (1995). Privatisation in Eastern Europe: Experience and Preliminary Policy Lessons. Chapter 2, pp.31-47, in P Cook and C Kirkpatrick (eds). Privatisation Policy and Performance: International Perspectives. New York: Harvester Wheatsheaf.

Scapens, R.W. and Yan, M. (1993). Management Accounting Research in China. Management Accounting Research .4. pp.321-341.

Shaoul, J. (1997). A Critical Financial Analysis of the Performance of Privatised Industries: The Case of the Water Industry in England and Wales. Critical Perspectives on Accounting. pp. 479-510.

Sobhan, R and Ahsan, A. (1984). Disinvestment \& Denationalisation: Profile and Performance, (Bangladesh Institute of development Studies: Research Report New Series, no.38, 1984).

Staker R.E. (1995). The Art of Case Study Research. London: Sage.

Sun, J. (1994).The Economic History of the People's Republic of China, Beijing: Chinese People's. University Press.

Sun, Q. and Tong, Wilson H.S. (2003). China's Share Issue Privatisation: The Extent of Its Success. Journal of Financial Economics.70. pp.183-222.

Thompson, G. (1982). The Firm as `Dispersed' Social Agency. Economy and Society. pp.233-250.

Thornton, J. (2001). The Real Story of UK Rail Privatisation, viewed November 2001, http://www.igreens.org.uk/real_story_of_uk_rail_privatisat.htm.

Tinker, A.M. (1980). A political economy of accounting. Accounting, Organizations and Society, 5, pp. 147-160.

Tyrrall, D. and Parker, D. (2001). The Fragmentation of a Railway: A study of organisational changes of British Rail. AFRU Working Paper 01/6.

Uddin, S. and Hopper, T. (1999). Management control, ownership and development: illustrations from a privatised Bangladeshi enterprise. Chapter 10, pp.231-271, in M Mackintosh and R Roy (eds) Economic Decentralization and Public Management Reform. Northampton: Edward Elgar Publishing.

Uddin, S. and Hopper, T. (2001). A Bangladesh soap opera: privatisation, accounting, and regimes of control in a less developed country. Accounting, Organizations and Society. 26. pp.643-672.

Uddin, S. and Hopper, T. (2003). Accounting for Privatisation in Bangladesh: Testing World Bank Claims. Critical Perspectives on Accounting. 14.pp.739-74. 
Uddin, S and Tsamenyi, M. (2005). Public Sector Reforms and the Public Interest: A Case Study of Performance Monitoring in a Ghanaian State-Owned Enterprise (SOE). Accounting, Auditing and Accountability Journal. 18 (5). pp. 648-675.

Vickers, J. and Yarrow, G. (1988). Privatisation: An economic Analysis. Cambrige: The MIT Press.

Wallace, R.S.O. (1988). Corporate Financial Reporting in Nigeria. Accounting and Business Research.18(72). pp.352-357.

$\mathrm{Xu}$, Y. and Xiang, J.Q. (1993). Chinese Finance in the Period of Seventh Five Year Plan, Beijing: Chinese Finance and Economics Press.

Wickramasinghe, D.P. (1996). Rationales of Accounting Controls and Ownership Change in a Development Context: A Mode of Production Theory Analysis of Two Sri Lankan Case Studies. Unpublished PhD thesis. Manchester School of Accounting and Finance. University of Manchester..

Wickramasinghe, D. P and Hopper, T. (2005). A cultural political economy of management accounting controls: a case study of a textile Mill in a traditional Sinhalese village. Critical Perspectives on Accounting. 16 (4). pp. 473-503.

World Bank (1980). Borrowing the International Capital Markets. Washington, DC: The World Bank.

World Bank (1992). Privatisation: The Lessons of Experience. Washington, DC: The World Bank.

World Bank (1995) Bangladesh: Privatisation and Adjustment, Bangladesh.

Wortzel, H. and Wortzel, L.H. (1989). Privatisation: Not the Only Answer. World Development, 17 (5). pp.633-641.

Wu, Z. (1997). How Successful Has State-Owned Enterprise Reform Been in China?' Europe-Asia Studies. 49 (7). pp. 1237-1262.

Yarrow, G. (1989). Privatisation and Economic Performance in Britain. Carnegie-Rochester Conference Series on Public Policy. 31. pp.303-344.

Yin, R.K. (2003). Case study research: design and methods. London: Sage.

Zhang, W.W. (2002). An empirical study of the regime changes in Chinese SOEs. Economic Science. 13. pp.27-34.

Zhou, Z.H. (1988). Chinese Accounting Systems and Practices. Accounting, Organizations and Society.13(2). pp.207-224. 
Figure 1 Return on Assets of HS from 1978 to 1994

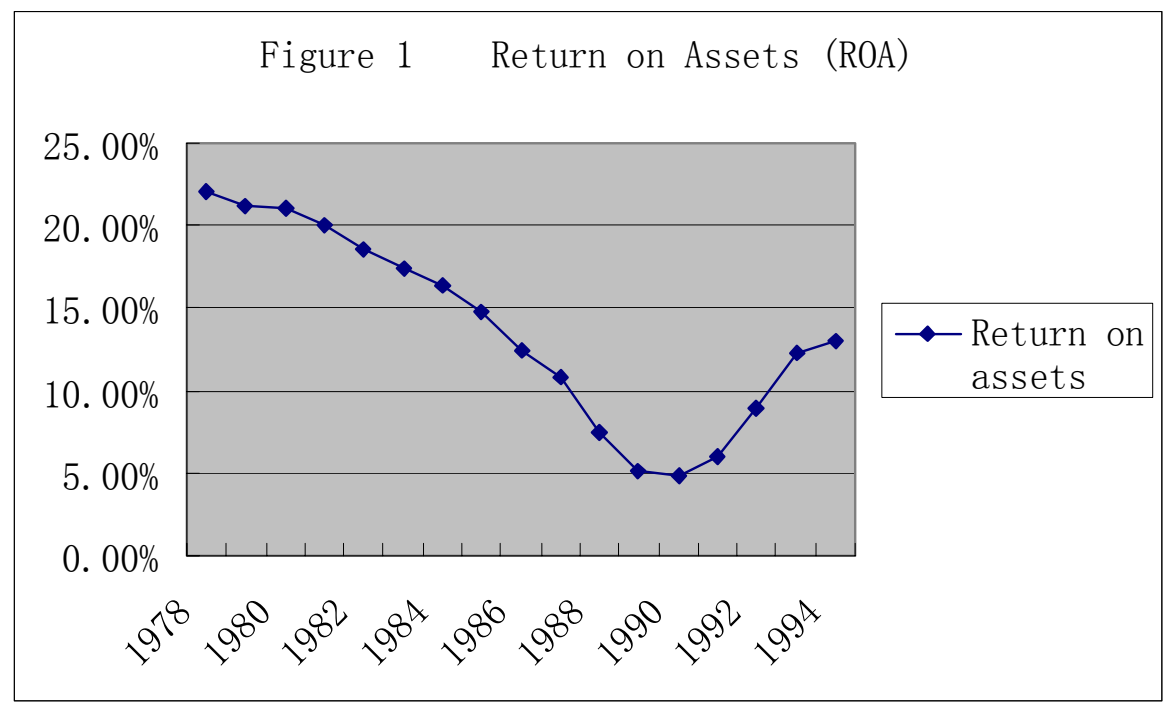

Figure 2 Sales, Profits and Taxes of HS from 1991 to 2004

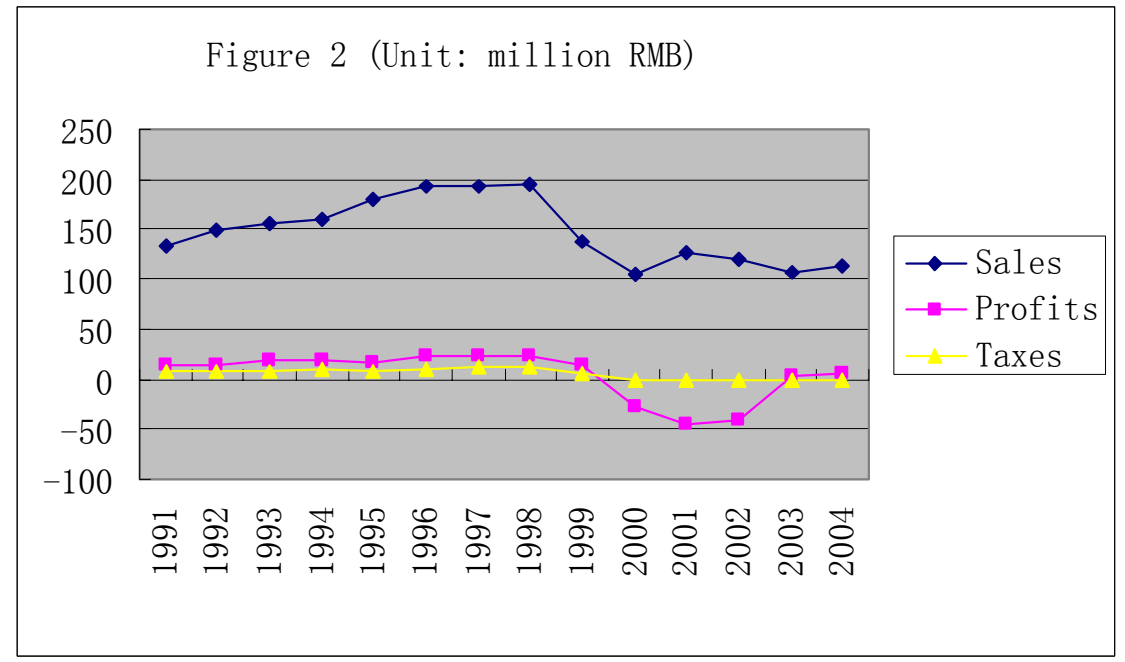

Figure 3 Return on Equity of HS from 1995 to 2004 


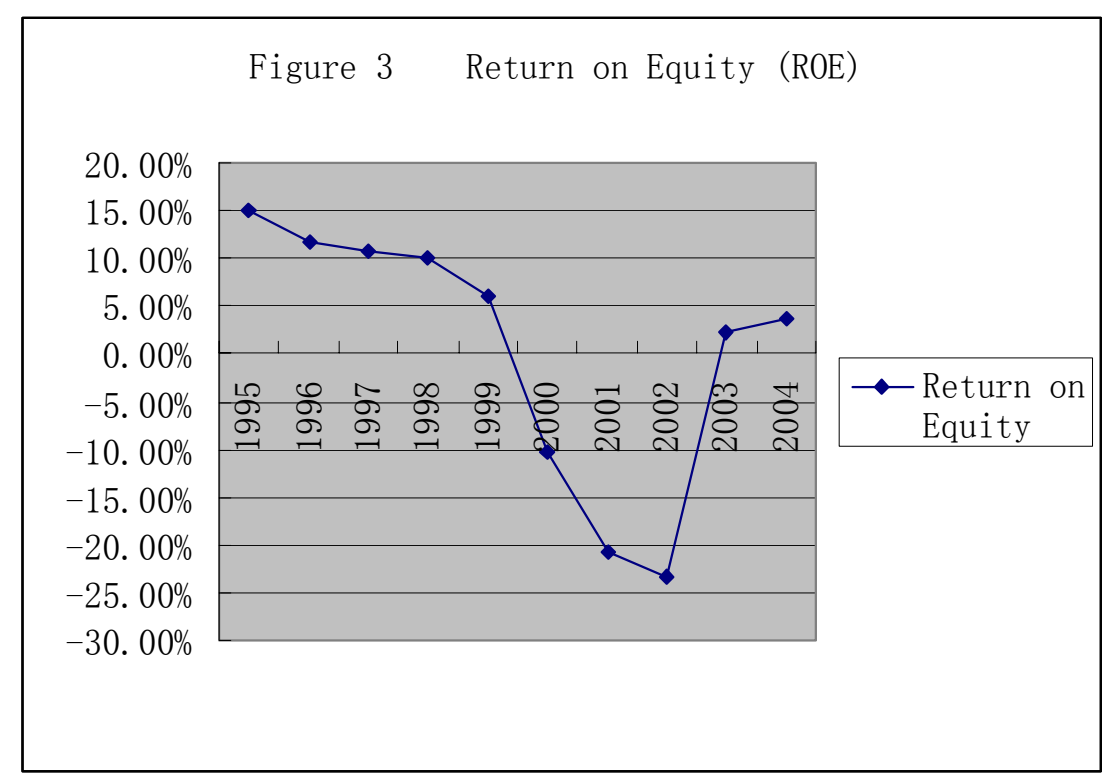

Table One Relative Shares of Chinese State-Owned, Mixed Ownership and Privately Owned Enterprises in Employment, 1993-1999.

\begin{tabular}{|c|c|c|c|c|c|}
\hline \multicolumn{6}{|c|}{ Employment in Chinese Industrial Enterprises (Staff and Workers) } \\
\hline Year & 1993 & 1995 & 1997 & 1998 & 1999 \\
\hline SOEs & 45. $0 \mathrm{~m}$ & $44.0 \mathrm{~m}$ & $40.4 \mathrm{~m}$ & $27.2 \mathrm{~m}$ & $24.1 \mathrm{~m}$ \\
\hline Share & $68 \%$ & $67 \%$ & $65 \%$ & $57 \%$ & $55 \%$ \\
\hline Collectives & $17.0 \mathrm{~m}$ & $15.0 \mathrm{~m}$ & $13.3 \mathrm{~m}$ & $8.0 \mathrm{~m}$ & $6.7 \mathrm{~m}$ \\
\hline Share & $26 \%$ & $23 \%$ & $21 \%$ & $17 \%$ & $15 \%$ \\
\hline Others $^{n}$ & $4.3 \mathrm{~m}$ & $7.1 \mathrm{~m}$ & $8.5 \mathrm{~m}$ & $12.3 \mathrm{~m}$ & $13.4 \mathrm{~m}$ \\
\hline Share & $6 \%$ & $10 \%$ & $14 \%$ & $26 \%$ & $30 \%$ \\
\hline TOTAL & $66.3 \mathrm{~m}$ & $66.1 \mathrm{~m}$ & $62.2 \mathrm{~m}$ & $47.5 \mathrm{~m}$ & $44.2 \mathrm{~m}$ \\
\hline Share & $100 \%$ & $100 \%$ & $100 \%$ & $100 \%$ & $100 \%$ \\
\hline
\end{tabular}

Source: Table 4 in Broadman (2001)

0 thers $^{\mathrm{n}}$ here refers to all private sector firms

1Liu (2000) testified to the higher efficiency of private firms over state enterprises, based on 195 census firm-level data for the steel industry alone. However, Jefferson (1999) argued that the declining profitability of those SOEs stems from increasingly keen competition with non-state enterprises, such as foreign and private firms, rather than from problems inherent in the SOEs themselves. Nakagane (2000) compared the profitability and efficiency of the state sector versus non-state sectors and pointed out that although public efficiency is lower than that of their non-state counterparts, the state enterprises distribute relatively more to their workers and employees. Thus, comparative studies of state enterprises versus private enterprises in China are contentious.

2Burawoy's work (1985) presented a historical analysis of control (factory regimes) in advanced capitalist, 
socialist (communist) and ex-colonial developing countries. Burawoy argues that bureaucratic despotism rather than hegemonic regimes of capitalism prevailed during communism. This is very relevant to the Chinese context, where enterprises were arms of the state and were controlled through a state central plan. However, enterprises had to bargain with the centre for resources whilst constantly improvising in the face of shortages. This led to enterprises having two sets of controls: the official central plan and less formal dealings between the enterprise and state officials. This gave rise to a core and a peripheral labour force. The core (often party members and trade union officials) managed tensions within the economic plan and curried favours from state bureaucrats and political officers, leaving peripheral workers to execute their tasks under coercive conditions (Uddin and Hopper, 2001). Burawoy also noted the gradual transformations of bureaucratic despotism into new despotic regimes, especially in poorer countries, due to the convergence of production and state politics, the ensuing conflicts, fiscal crises, and pressures from agents of international capital for market reforms. Poor countries, in a bid to improve enterprise performance, often turn to programmes of economic liberalisation based on export processing zones, privatisation, and touting the attractions of cheap, economically weak, unprotected labour to national and international capital. The new control regimes in China, we believe, are not far from becoming a new despotic regime.

3Before 1978, the government under Mao Zedong was based on a fusion of economics and politics: the Communist Party's monopoly of political power rested on state-ownership of the vast bulk of productive assets, the replacement of the market by centralised planning, and Party control of the careers of enterprise managers and state bureaucrats (Wu, 1997).

4Productive efficiency stems from micro-economic theories of property rights and agency within contractual relationships (Adam et al., 1992), whereas allocative efficiency covers the macro-economic effects of privatisation upon public finances, capital markets and private sector investments (Cook and Kirkpatrick, 1995).

5Boardman and Vining (1988) developed a typology of the behaviour of mixed enterprises and found that if the government's proportion of total shares is high and concentrated, there will be high government owner control and pressure to fulfil the goal of the public owner; if the government's proportion of shares is low and private shares are concentrated, there will be high private owner control and strong profit-maximising pressure. Cragg and Dyck (1999) provided a test for the relationship between ownership and incentives. They measured management replacement after privatisation in the UK and the sensitivity of management replacement to changes in financial performance, and argued, 'management accountability is lacking in SOEs but increases following privatisation.' They further concluded that privatisation has a significant impact on internal control systems. Martin and Parker (1997) measured two efficiency indices - labour productivity and TFP - in 11 UK privatised companies and concluded, 'it appears that ownership change was associated with improved efficiency in a majority of cases, but it does not necessarily follow that privatisation caused the improvement.' Also, Karatas' empirical study (1995) in Turkey found that privatisation does not have a significant effect on enterprise efficiency. Andrews and Dowling (1998) further argued that privatisation is associated with new forms and an increased prominence of financial reporting and control to reflect the new strategic orientation and organisational structures. Jones's study (1985) shed light on the role of management accounting systems (MAS) following a takeover or merger and drew the conclusion that accounting-type controls probably play a much more important role than is generally acknowledged. His subsequent research (1992) on changes of MAS following management buy-out showed that owner-managers use MAS in a selective manner to facilitate changes in organisational structures and in the attitudes of participants, and to improve efficiency and profitability. More recently, Tyrrall and Parker (2001) investigated the changes of accounting systems in British Railways after privatisation and found that, 'new and separate accounting system have been purchased for all 
the parts of British Railways instead of the former diagnostical system.' However, the competitive argument was addressed by Letza and Smallman (2001). They claimed that the privatisation of Yorkshire Water had not brought about improved accounting, and had failed because it was too focused on aligning directors' and shareholders' interests and ignored the public good.

6The paper does not present a detailed account of CRS, not only due to the scope of the paper but also because of a lack of information due to time and resource constraints. Nevertheless, previous studies in China have commented on CRS in detail.

7Information on the failure of the governance mechanisms is limited due to limited access to documents.

8Firstly, the central government did not set clear rules on the method of transfer, so local authorities were left to formulate their own criteria and procedures. Secondly, local governments have long been plagued by the huge losses of their SOEs and limited government financial resources; thus, they have had strong incentives to divest their SOEs as rapidly as possible. That is why they have given more emphasis to outright sales and other modalities entailing little or no further assistance from local authorities. 